УДК $53(07)+374+519.7$

Іваницька Наталія Анатоліївна

кандидат педагогічних наук, заступник директора 3 навчально-виховної роботи

Чернігівський ліцей № 32,_м. Чернігів, Україна

ivanytska@bigmir.net

Стрижак Олександр Євгенійович

кандидат технічних наук, заступник директора з наукової роботи

Національний Центр «Мала академія наук України», м. Київ, Україна

sae953@gmail.com

\title{
ОСОБЛИВОСТІ ОНТОЛОГІЇ ЯК ЗАСОБУ ОРГАНІЗАЦІЇ САМОСТІЙНОЇ РОБОТИ СТАРШОКЛАСНИКІВ, ЗДІБНИХ ДО ДОСЛІДНИЦЬКОї ДІяЛЬНОСТІ
}

\begin{abstract}
Анотація. У статті розглядається розроблена нами структура онтології з фізики, побудована на основі веб-квесту, і відповідні її складові. Описані можливості сучасної навчальної комп'ютерної програми «GraphEditor», яка вказує учням маршрут самостійного теоретичного дослідження. Визначені основні етапи застосування онтології старшокласниками і сформульовані дидактичні проблеми управління вчителями навчальним процесом. Проаналізовані взаємозв'язки складових, візуалізацію яких забезпечує навчальна комп'ютерна програма «GraphEditor». Виділені особливості онтології як засобу організації самостійної роботи учнів. На основі нормативних документів доведено доцільність застосування онтології як засобу дистанційного навчання старшокласників, здібних до дослідницької діяльності.
\end{abstract}

Ключові слова: онтологія; фізика; веб-квест; структура онтології; комп'ютерна програма «GraphEditor»; складові онтології, застосування онтології; навчання старшокласників; особливості онтології.

\section{1. ВСТУП}

Постановка проблеми. Самостійність як якість особистості найбільш виявляється і розвивається в учнів під час розв'язування різних класів прикладних задач. Особливо це проявляється у процесі вивчення фізичних основ навколишнього середовища. Саме тому у шкільній практиці звертається особлива увага на формування самостійної роботи як навчальної діяльності учнів й удосконалення методики іiі організації. Відповідно, виникає проблема: які засоби навчання забезпечують самостійну роботу учнів, здібних до дослідницької діяльності. Ця проблема пов'язана 3 розв'язанням такого практичного завдання: формування у старшокласників умінь здобувати і застосовувати на практиці нові знання.

Аналіз останніх досліджень і публікацій. Самостійність учнів у дидактиці розглядається по-різному: 1) форма організації навчального процесу (В. Д. Мороз [9, с. 6]), засіб навчання (П. І. Підкасистий [10, с. 175]), особливий вид навчальнопізнавальної діяльності (А. В. Петрова [11, с. 16-19]); 2) вид роботи учнів і структурні компоненти методики їі організації: а) організаційна форма - домашня навчальна робота, семінари та практикуми, предметні гуртки й факультативи, курси за вибором, предметні олімпіади і конкурси (А. Т. Ашеров [1, с. 51]); б) метод навчання - робота 3 навчальними ресурсами у друкованому чи цифровому форматах, розв'язування задач, спостереження, навчальний експеримент, конструювання та моделювання, навчальне проектування (Л. Є. Сігаєва [14, с. 114-127]); в) дидактичний засіб - підручники, посібники (М. В. Каленик [7, с. 188-194]); в) інструментальний засіб - інформаційнокомунікаційний засіб навчання (А. В. Козаков [8, с. 15]); 3) прояв у формах навчання: 
підготовка до контрольних робіт, іспитів; виконання практичних завдань; написання рефератів, підготовка до олімпіад; 4) рівень діяльності: репродуктивна, варіативна, реконструктивна, творча (М. М. Солдатенко [15, с. 127]).

Отже, тлумачення поняття «самостійність учнів» залежить від того, яку дидактичну мету обирає вчитель для навчання фізики старшокласників. Оскільки, згідно проведених нами попередніх теоретичних досліджень, самостійність — це особистісний критерій сформованості навчально-пізнавальних компетентностей учнів, здібних до дослідницької діяльності, то поняття «самостійність учнів» ми розглядаємо перш за все як вид їхньої навчально-пізнавальної діяльності.

Мета статті. Враховуючи запропоноване нами тлумачення поняття самостійності, 3'являється необхідність у виявленні інших критеріїв сформованості навчально-пізнавальних компетентностей учнів 3 фізики, у встановленні їхніх взаємозв'язків. Тому метою нашої статті є комплексне розв'язання сформульованої проблеми, тобто вибір засобів самостійної навчальної діяльності старшокласників.

\section{2. МЕТОДИ ДОСЛІДЖЕННЯ}

Дослідження проводилось у рамках роботи творчої групи Національного центру «Мала академія наук України». Під час дослідження використовувались такі методи: аналіз теоретичних джерел 3 проблем використання онтологій в інформаційних системах, дослідження методик підвищення мотивації учнів до самостійного навчання, узагальнення передового досвіду організації застосування інформаційних технологій для організації творчої науково-дослідницької роботи учнів у Малій академії наук.

\section{3. РЕЗУЛЬТАТИ ДОСЛІДЖЕННЯ}

Сформованість навчально-пізнавальних компетентностей старшокласників 3 фізики, згідно досліджень, проведених нами раніше [5; 6], визначається не за одним критерієм (особистісним), а за такою їхньою сукупністю: управлінський критерій, мотиваційний та інформаційно-комунікаційний. Згідно наказу Міністерства освіти і науки України № 466 від 25.04.2013 р. «Про затвердження Положення про дистанційне навчання» у загальноосвітніх навчальних закладах зростає роль інформаційнокомунікаційних технологій, тобто технологій «створення, накопичення, зберігання та доступу до веб-ресурсів (електронних ресурсів) навчальних дисциплін (програм), а також забезпечення організації і супроводу навчального процесу за допомогою спеціалізованого програмного забезпечення та засобів інформаційно-комунікаційного зв'язку, у тому числі Інтернету» [12]. Відповідно, це Положення підтверджує зв'язок управлінського й інформаційно-комунікаційного критеріїв. Згідно зазначеного нормативного документу [12], використання технологій дистанційного навчання зорієнтоване, насамперед, на обдарованих дітей і молодь, які спроможні самостійно або прискорено опанувати навчальні програми. Це дозволяє нам стверджувати, що інформаційно-комунікаційний критерій сформованості навчально-пізнавальних компетентностей учнів безпосередньо пов'язаний з особистісним критерієм. Отже, зазначені критерії сформованості навчально-пізнавальних компетентностей учнів 3 фізики не лише взаємопов'язані між собою, а й передбачають комплексне розв'язання сформульованої проблеми, тобто вибір засобів самостійної навчальної діяльності старшокласників.

Враховуючи важливу дидактичну i мотиваційну роль інформаційнокомунікаційних технологій у навчально-виховному процесі, ми пропонуємо 
організовувати самостійну дослідницьку діяльність учнів, які навчаються у класах фізико-математичного профілю, на основі застосування комп'ютерних онтологій предметних галузей. У межах нашого дослідження під поняттям «онтологія» ми розуміємо спосіб, який використовується для опису фізичних знань, зокрема базових понять цієї сфери, їхніх властивостей і зв' язків між ними. У науковій літературі $[2 ; 3 ; 4$; $16 ; 17]$ зазначено, що онтологія — це надійний семантичний базис у визначенні змісту; загальна логічна теорія, що складається зі словника-тезаурусу і набору тверджень на деякій мові логіки; основа для комунікації між людьми й комп'ютерними агентами. Отже, онтологія як засіб самостійного навчання учнів дослідницькій діяльності передбачає: 1) чітку логічну структуру, зміст якої узгоджується 3 навчальною програмою за тематикою предметної галузі, у нашому представленні - фізики; 2) підпорядкування єдиній дидактичній меті; 3) компактність представлення основних змістовних положень.

3 метою розробки змісту відповідної онтології і їі практичного використання у навчальній діяльності як учителями, так і учнями старших класів, нами була обрана за основу сучасна комп'ютерна програма «GraphEditor» [2]. Вона забезпечує побудову семантичної мережі понять у вигляді онтології [2; 3; 4], їх аналізу, виявлення та формування закономірностей. Під час побудови певної онтології, система створює таксономію 3 множини понять, які будуть використовуватися учнями під час розв'язування прикладних завдань. Для цього треба визначити класи понять за їхніми властивостями. 3 точки зору методики доцільно формувати класи понять за темами певних розділів навчального предмету, а за ім'я класу — обирати назву певної теми. Тому центральною вершиною кожної онтології ми обираємо певний розділ фізики, який узгоджується 3 діючою навчальною програмою 3 фізики для учнів 10-11-х класів фізико-математичного профілю, наприклад розділ «Електричне поле». Допоміжною вершиною є тема 3 цього розділу, з якої ми пропонуємо учням проводити самостійне дослідження, наприклад «Конденсатори та їх використання у техніці». Оскільки будьяке навчальне дослідження з фізики передбачає теоретичну і практичну діяльність учнів, то зміст онтології ми систематизуємо за двома напрямками: «Теоретичні основи» i «Практична робота». Згідно проведеного нами раніше вивчення теоретичного матеріалу, самостійна дослідницька діяльність учнів потребує дотримання певного плану дій. Тому ми пропонуємо обирати за основу онтології певний «маршрут» учнівського дослідження, тобто веб-квест. Відповідно, наступну допоміжну вершину онтології ми називаємо «Теоретичні основи веб-квесту». Між зазначеними вершинами вказуємо логічні зв’язки: від центральної вершини до допоміжних (рис. 1).

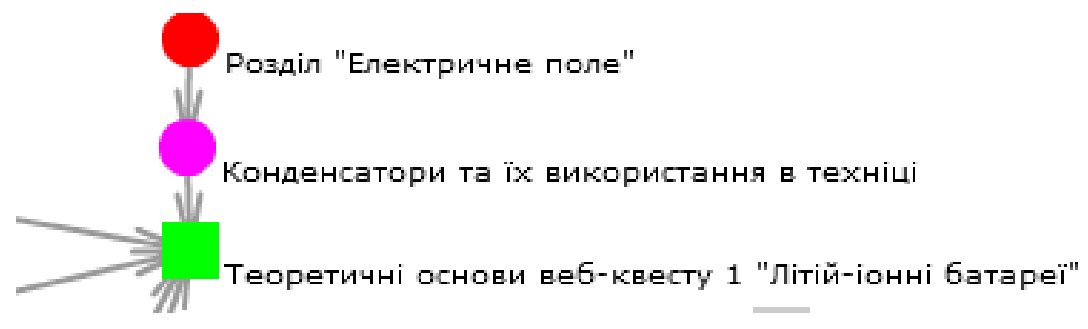

Рис. 1. Фрагмент онтологї розділу «Електричне поле»

Розглянемо один із напрямків онтології - «Теоретичні основи», який також у загальній схемі позначається відповідною вершиною. Оскільки веб-квест, який лежить в основі онтології, згідно проведеного нами попереднього аналізу наукової літератури, містить 3 етапи проведення учнями теоретичного дослідження, то онтологія містить такі допоміжні вершини: «Підготовчий етап», «Виконавський етап», «Підсумковий 
етап». Ha nidzomoвчому emani індивідуальна робота учнів над веб-квестом, у основі якого лежить онтологія, спрямована на самостійне визначення ними об'єкта, предмета та мети дослідження. Для цього необхідно старшокласникам проаналізувати означення пристрою, запропонованого для вивчення, принцип дії, параметри та фізичні явища, покладені в основу його роботи. Зазначені етапи роботи учнів відображені в онтології відповідними вершинами (рис. 2).

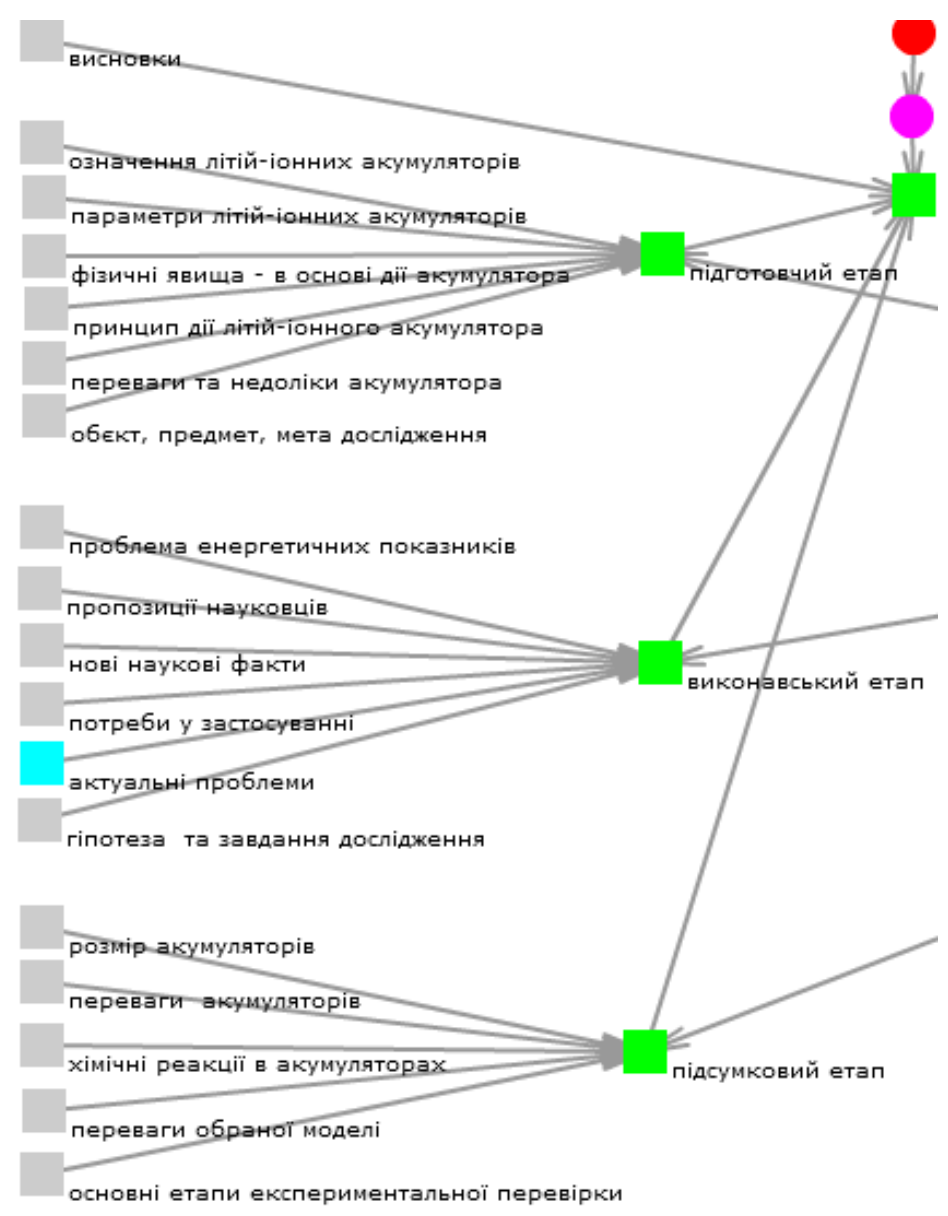

Рис. 2. Фрагмент онтології розділу «Електричне поле», де відображені складові підготовчого, виконавського та підсумкового етапів вериини «Теоретичні основи»

Особливість зазначених вершин (крім вершини «Об’єкт, предмет, мета дослідження») полягає в тому, що вони містять гіперпосилання на Інтернет-джерела, використовуючи які, учні одержують інформацію, необхідну їм для проведення самостійного аналізу. Оскільки Інтернет-джерела структуровані на основі вершин, то це спрощує пошук старшокласниками інформації, потрібної для самостійного формулювання ними об'єкта, предмета та мети дослідження. Таким чином, використання онтології на підготовчому етапі проведення учнями теоретичного дослідження дозволяє нам виділити таку особливість онтології як засобу організації самостійної роботи учнів: надає учням можливість вибору важливих для дослідження фактів на основі сучасної інформації, адаптованої до рівня навчальної програми 3 фізики для учнів 10-11-х класів фізико-математичного профілю.

Перед роботою учнів на цьому етапі вчитель аналізує разом з ними, як обирати головне у поданій для вивчення інформації, повторює разом з учнями загальнодидактичні принципи аналізу фізичного явища, пристрою, механізму, 3 якими 
старшокласники були ознайомлені ще в основній школі. Після самостійного виконання учнями завдань на підготовчому етапі теоретичного дослідження, завдання вчителя полягає у перевірці одержаних учнями результатів, їх спільному обговоренні й коригуванні.

Особливо це стосується вершини графа, яка не містить гіперпосилання на Інтернет-джерела) «Об'єкт, предмет, мета дослідження», оскільки вона є ключовою на цьому етапі і виражає головну ідею й результати самостійної теоретичної роботи учнів. Відповідно, виникає питання щодо часу використання зазначеної онтології у навчально-виховному процесі - на уроці чи в післяурочний час (на заняттях фізичного гуртка). Запропонована нами онтологія є засобом формування навчально-пізнавальних компетентностей старшокласників, здібних до дослідницької діяльності, i iii зміст узгоджується із змістом навчальної програми 3 фізики для учнів 10-11-х класів фізикоматематичного профілю. Зміст зазначеної онтології також відповідає програмі 3 позашкільної освіти (дослідницько-експериментального напряму), затвердженій Міністерством освіти і науки України [13, с. 41-53]. Отже, узгодженість із зазначеними навчальними програмами надає можливості розробленій нами онтології застосовуватись вчителями як під час уроку для індивідуальної роботи з обдарованими учнями, так і в позаурочний час для гурткової роботи. Це дає право нам стверджувати, що онтологія $\epsilon$ універсальною для роботи 3 обдарованими учнями, здібними до дослідницької діяльності з фізики.

На виконавському етапі самостійна робота учнів над веб-квестом, який лежить в основі запропонованої нами онтології, полягає у формулюванні гіпотези і завдань дослідження на основі виявлення з обраної тематики існуючих проблем, ознайомлення 3 пропозиціями науковців щодо їх розв'язання, вивчення нових наукових фактів, обгрунтування потреб у застосуванні певного фізичного явища, пристрою та ін. Зазначені етапи роботи учнів відображені в онтології відповідними вершинами (рис. 2), які, крім вершини «Гіпотеза та завдання дослідження», містять гіперпосилання на Інтернет-джерела 3 метою ознайомлення учнів із необхідною для дослідження інформацією. У розробленій нами онтології вершина «Актуальні проблеми» містить відео Інтернет-джерела. Це зроблено з метою візуалізації фізичних явищ, демонстрації принципу дії фізичних приладів, підвищення мотивації вивчення обраної теми дослідження. Отже, використання онтології на виконавському етапі проведення учнями теоретичного дослідження дозволяє нам виділити таку особливість онтології як засобу організації самостійної роботи учнів: враховує психологічні особливості навчання старшокласників, які потребують вмотивованої діяльності.

Завдання вчителя на цьому етапі полягає в тому, щоб після виконання учнями теоретичного дослідження надати учням роз'яснення з тих питань, які виявилися для них проблемними, тобто вчитель здійснює консультаційну допомогу. Оскільки робота учнів з вершинами, які містять гіперпосилання на Інтернет-джерела, була спрямована на досягнення ключової вершини цього етапу - формулювання гіпотези і завдань дослідження, то це передбачає відповідну перевірку вчителем.

Ha nidсумковомy emani теоретичного дослідження самостійна робота учнів спрямована на досягнення ними ключової вершини маршруту «Основні етапи експериментальної перевірки» (рис. 2). Головним завданням учнів на цьому етапі $\epsilon$ теоретичне обгрунтування власної ідеї дослідження i розробка плану іiі експериментальної перевірки. Для цього учні використовують маршрут, зазначений в онтології (рис. 2), використовуючи відповідні гіперпосилання на Інтернет-джерела. Особливістю інформації, яку містить підсумковий етап онтології для проведення учнями самостійного теоретичного дослідження, $є$ те, що використовуються посилання на відповідні матеріали сайтів сучасних світових наукових лабораторій. Наприклад, 
сайт Аргонської Національної Лабораторії (м. Чикаго, США), на базі якої у 2013 році відповідно до наказу Міністерства освіти і науки, молоді та спорту України №1/9-427 від 12.06.2013 р. «Про проведення Першої наукової школи в Аргонській Національній Лабораторії» навчалася у групі вчителів України співавтор статті. Тому врахування учнями сучасних напрямків дослідження світових лабораторій впливає на формування у старшокласників власної моделі дослідження 3 фізики i на планування iі експериментальної перевірки. Отже, використання онтології на підсумковому етапі проведення учнями теоретичного дослідження дозволяє нам виділити таку особливість онтології як засобу організації самостійної роботи учнів: формує в учнів об'єктивний погляд на власні ідеї дослідження порівняно з пропозиціями сучасних науковців.

Завдання вчителя на цьому етапі полягає в тому, щоб надати старшокласникам консультаційну допомогу щодо розробки власної моделі дослідження і складання плану іï експериментальної перевірки. Відповідно, учитель коригує результати самостійної роботи учнів.

На кожному із зазначених етапів самостійного теоретичного дослідження учнів (підготовчий, виконавський, підсумковий), які є вершинами онтографів запропонованої нами онтології, передбачено ознайомлення учнів із практичним застосуванням одержаних знань на практиці (рис. 3). Відповідні вершини онтографів містять інформацію про сучасні прилади, матеріали, речовини, їхні особливості, переваги застосування на практиці та ін.
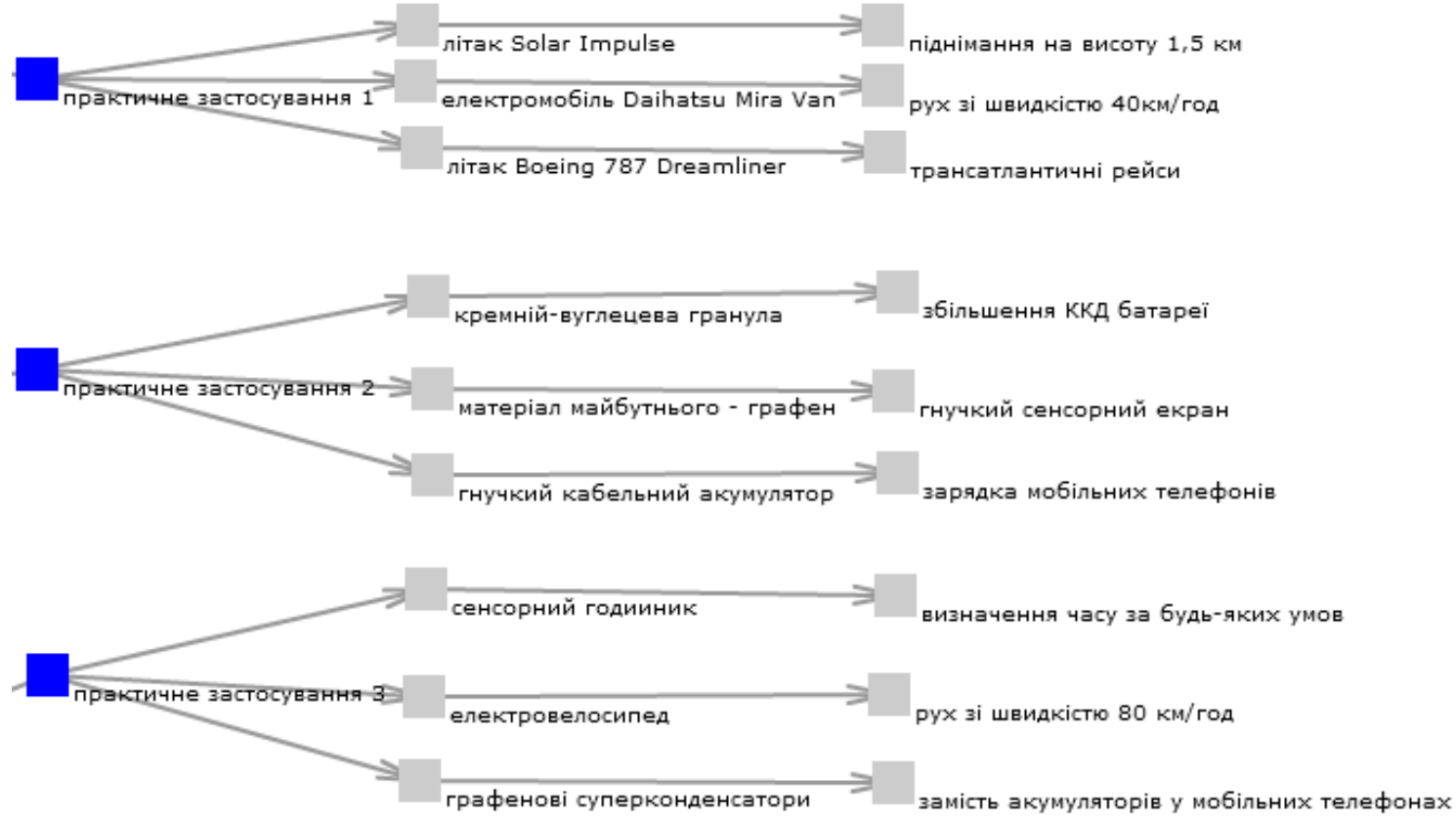

Рис. 3. Фрагмент онтології розділу «Електричне поле», де відображені напрямки його практичного застосування

Особливістю інформації, яку містять гіперпосилання на Інтернет-джерела до зазначених вершин графів, $є$ те, що переважна їх більшість розкриває сучасні наукові методи застосування нанотехнологій. Отже, використання онтології для демонстрації учням напрямків практичного застосування теми, обраної для дослідження, дозволяє нам виділити таку особливість онтології як засобу організації самостійної роботи учнів: пропагує практичне застосування сучасних технологій.

Відповідно, розроблена нами онтологія як засіб організації самостійної роботи старшокласників має чітку логічну структуру, яка містить такі складові: центральну вершину, дочірні вершини онтографу і низку підпорядкованих ним вершин, ключові 
вершини. Логічні зв’язки, представлені у загальній структурі онтології, вказують старшокласникам відповідний маршрут їхнього руху щодо проведення самостійного теоретичного дослідження.

Ключові вершини («Об’ єкт, предмет, гіпотеза дослідження», «Гіпотеза та завдання дослідження», «Основні етапи експериментальної перевірки») не містять гіперпосилань, оскільки передбачають самостійне формулювання старшокласниками одержаних висновків, які стануть основою для власної моделі дослідження. Тому ми окремо виділяємо вершину графу «Висновки» (рис. 4). Відповідно, результати роботи, які представлені цими вершинами, потребують перевірки вчителем і відповідного коригування.

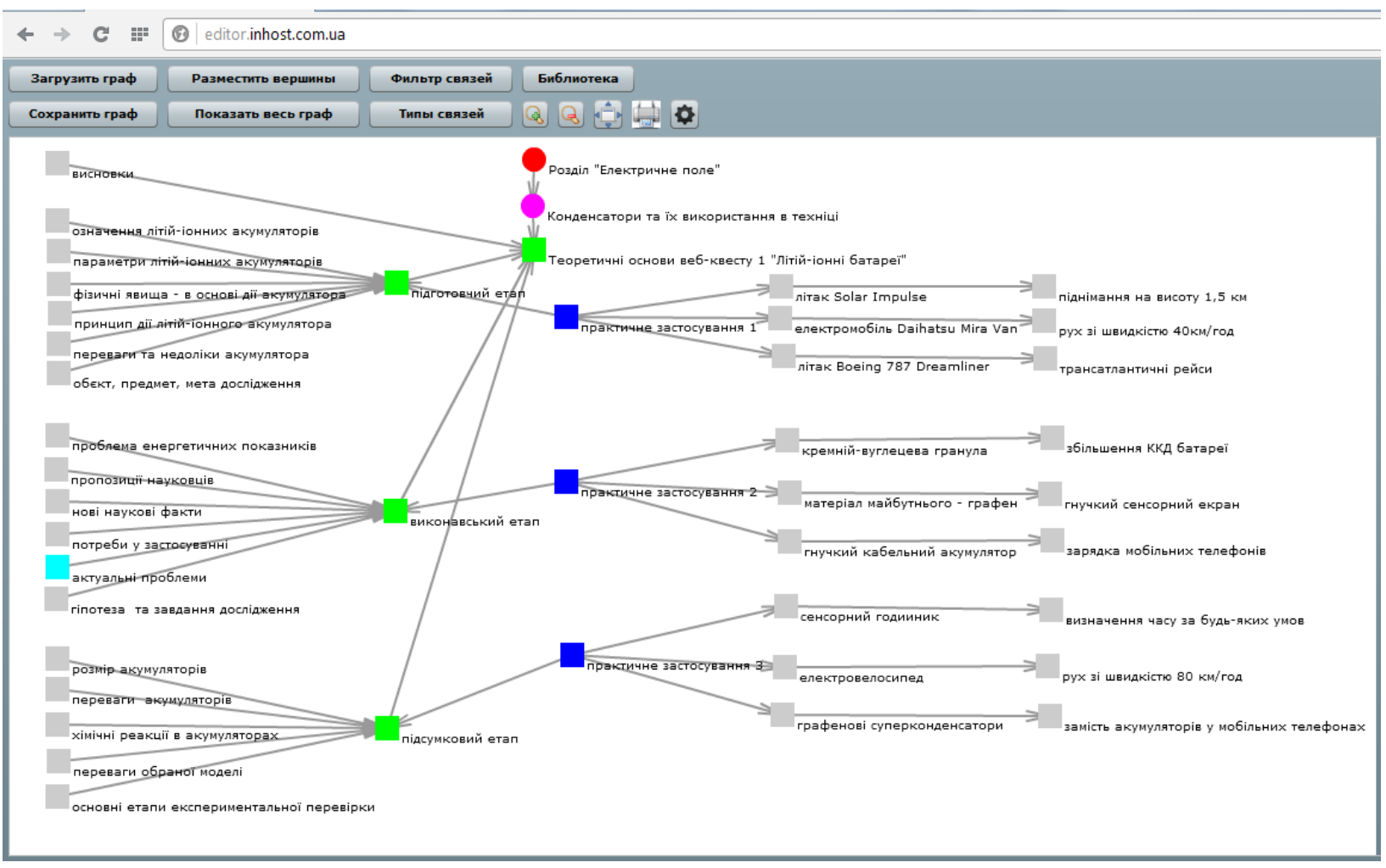

Рис. 4. Загальна структура онтологї розділу «Електричне поле»

\section{4. ВИСНОВКИ ТА ПЕРСПЕКТИВИ ПОДАЛЬШИХ ДОСЛІДЖЕНЬ}

Проведений нами аналіз структури і змісту онтології дозволив обрати іiі таким засобом навчання, який забезпечує самостійну роботу учнів, здібних до дослідницької діяльності, і виявити низку особливостей. Відповідно, нами була визначена нова проблема, пов'язана 3 практичним застосуванням онтології: як учителеві здійснити контроль за етапами виконання учнями самостійної роботи. Зазначена проблема має такі перспективи подальших досліджень: 1) виявлення особливостей онтологічного підходу до навчання експериментальній діяльності обдарованих учнів; 2) визначення методів контролю за самостійною діяльністю учнів.

\section{СПИСОК ВИКОРИСТАНИХ ДЖЕРЕЛ}

1. Ашеров А. Т. Методи і моделі оцінки педагогічного впливу на розвиток пізнавальної самостійності студентів / А. Т. Ашеров, В. Г. Логвіненко. — Х. : УІПА, 2005. — 164 с. 
2. Величко В. Автоматизированное создание тезауруса терминов предметной области для локальных поисковых систем / В. Величко, П. Волошин, С. Свитла // "Knowledge — Dialogue — Solution" International Book Series "INFORMATION SCIENCE \& COMPUTING”, Number 15. — FOI ITHEA Sofia, Bulgaria. - 2009. - Pp. 24-31.

3. Гладун В. П. Процессы формирования новых знаний [Текст] / В. П. Гладун. - София : СД «Педагог 6», 1994. - 192 с.

4. Дем'яненко В. Б. Онтологічні аспекти побудови е-сценарію супроводу процесу наукових досліджень учнів Малої академії наук України [Текст] / В. Б. Дем'яненко, С. П. Кальной, О. С.Стрижак // Інформаційні технології в освіті : збірник наукових праць. - Випуск 15. - Херсон : ХДУ, 2013. - С. 242-249.

5. Іваницька Н. А. Домінуючі складові моделей компетентностей учнів 10-х - 11-х класів як основа якісного навчання фізики / Н. А. Іваницька // Наукові записки. - Випуск 4. - Серія: Проблеми методики фізико-математичної і технологічної освіти. Частина 2. - Кіровоград : РВВ КДПУ ім. В. Винниченка, 2013. - С. 120-124.

6. Іваницька Н. А. Моделі компетентностей старшокласників / Н. А. Іваницька // Засоби і технології сучасного навчального середовища : матеріали конференції, м. Кіровоград, 17-18 травня 2013 року / відповідальний редактор: С. П. Величко. - Кіровоград : ПП «ексклюзив-систем», 2013. C. 100-101.

7. Каленик М. В. Методика організації самостійної роботи учнів з навчальною літературою / М. В. Каленик // Педагогічні науки: теорія, історія, інноваційні технології. — 2011. — № 1 (11). — С. 188-194.

8. Козаков В. А. Самостоятельная работа студентов и ее информационно-методическое обеспечение: Учебн. пособие. - К.: Вища школа, 1990. - С. 15.

9. Мороз В. Д. Самостійна навчальна робота студентів : монографія / Мороз В. Д. - Х. : ХМК, 2003. $-64 \mathrm{c}$.

10. Педагогика / под ред. П. И. Пидкасистого. - М. : Педагогика, 1996. - 602 с.

11. Петрова А. В. Дидактичні умови організації самостійної навчально-пізнавальної діяльності студентів / А. В. Петрова // Рідна школа. - 2006. - № 7. - С. 16-19.

12. Положення про дистанційне навчання. Режим доступу : http://zakon1.rada.gov.ua/laws/show/z070313.

13. Програми з позашкільної освіти. Дослідницько-експериментальний напрям / [О.О.Ар-тем’єва, С. Ю. Білоус, О. В. Биковська та ін.; упоряд. О. В. Лісовий, С. О. Лихота]. — К. : ТОВ «Інформаційні системи», 2010. - Вип. 1. - 150 с.

14. Сігаєва Л. Є. Вміння й навички самостійної роботи у професійному становленні дорослої людини : навч.-метод. посіб. / Л. Є. Сігаєва, М. Г. Гордієнко. — К. : Вид-во «ЕКМО», 2007. — С.114-127.

15. Солдатенко М. М. Теорія і практика самостійної пізнавальної діяльності : монографія / Микола Миколайович Солдатенко. — К. : Видавництво НПУ імені М. П. Драгоманова, 2006. — 198 с.

16. Gruber T. R. A translation approach to portable ontology specifications / T. R. Gruber // Knowledge Acquisition. - 1993. - Vol. 5. - P. 199-220.

17. Maedche A., Staab S. Tutorial on Ontologies: Representation, Engineering, Learning and Application // ISWC'2002.

Матеріал надійшов до редакиіï 26.01.2014 p.

\title{
РОЛЬ ОНТОЛОГИИ В СИСТЕМЕ ФОРМИРОВАНИЯ УЧЕБНО- ПОЗНАВАТЕЛЬНЫХ КОМПЕТЕНТНОСТЕЙ ПО ФИЗИКЕ У СТАРШЕКЛАССНИКОВ
}

\author{
Иваницкая Наталья Анатольевна \\ кандидат педагогических наук, заместитель директора по учебно-воспитательной работе \\ Черниговский лицей № 32, г. Чернигов, Украина \\ ivanytska@bigmir.net
}

\section{Стрижак Александр Евгеньевич}

кандидат технических наук, заместитель директора по научной работе Национальный центр «Малая академия наук Украины», г. Киев, Украина sae953@gmail.com 


\begin{abstract}
Аннотация. В статье рассматривается разработанная нами структура онтологии по физике, построенная на основе вэб-квэста, и соответствующие ее составляющие. Описаны возможности современной учебной компьютерной программы «GraphEditor», которая указывает ученикам маршрут самостоятельного теоретического исследования. Определены основные этапы применения онтологии старшеклассниками и сформулированы дидактические проблемы управления учителями учебным процессом. Проанализированы взаимосвязи составляющих, визуализацию которых обеспечивает учебная компьютерная программа «GraphEditor». Выделены особенности онтологии как средства организации самостоятельной работы учеников. На основе нормативных документов доказана целесообразность применения онтологии как средства дистанционного обучения старшеклассников, способных к исследовательской деятельности.
\end{abstract}

Ключевые слова: онтология; физика; вэб-квэст; структура онтологии; компьютерная программа «GraphEditor»; составляющие онтологии; применение онтологии; обучение старшеклассников; особенности онтологии.

\title{
ROLE OF ONTOLOGY IN THE SYSTEM OF FORMATION OF EDUCATIONAL AND COGNITIVE COMPETENCES ON PHYSICS OF SECONDARY SCHOOL PUPILS
}

\author{
Nataliia A. Ivanytska \\ Ph.D (pedagogical sciences), the Deputy Director \\ Lyceum №32, Chernihiv, Ukraine \\ ivanytska@bigmir.net \\ Oleksandr Ye. Stryzhak \\ Ph.D (Technical Sciences), the Deputy Director \\ National Center «Minor Academy of Sciences of Ukraine», Kyiv, Ukraine \\ sae953@gmail.com
}

\begin{abstract}
The article considers the structure of ontology on physics and its parts, which was built on the basis of webquest. We describe possibilities of modern computers program «GraphEditor», directing a route for pupils in their own theoretical research. Also, it was determined basic steps of the ontology and described how to use it in teaching. We analyzed didactic problems of the ontology application that establish visualization of ties when we use computers program «GraphEditor», as well as distinguished peculiarities of the ontology that organize an independent work of pupils. On the basis of regulatory documents proved the feasibility of the ontology as means of distance learning for upper-form pupils which are capable for research.
\end{abstract}

Keywords: ontology; physics; webquest; structures of ontology; computers program «GraphEditor»; peculiarities of ontology; application of ontology.

\section{REFERENCES (TRANSLATED AND TRANSLITERATED)}

1. Asherov A. T. Methods and models of estimation of pedagogical influence of development of independence of students / A. T. Asherov, V. G. Logvinenko. - H. : UIPA, 2005. — 164 p. (in Ukrainian)

2. Velichko V. Automatics' creation of tezarius of terms of district for local search systems / V. Velichko, P. Voloshin, S. Svitla // "Knowledge — Dialogue — Solution" International Book Series "INFORMATION SCIENCE \& COMPUTING”, Number 15. — FOI ITHEA Sofia, Bulgaria. — 2009. — Pp. 24-31. (in Ukrainian)

3. Gladun V.P. The processes of formation of new knowledge [Text] / V. P. Gladun. — Sofia : SD "Pedagog", 1994. — 192 p. (in Russian)

4. Demyanenko V. B. Aspects of ontology for creating e-script support of the process of science research of students of Minor academy of science of Ukraine [Text] / V. B. Demyanenko, S. P. Kalney, O. E. Stryzhak // Information technology of science in education: Compilation of science works. — Vol.15. Herson: HDU, 2013. — P. 242-249. (in Ukrainian) 
5. Ivanytska N. A. The dominant structure of the model of competence of students of 10-th - 11-th forms like basic of quality of education of physics / N. A. Ivanytska // Science note. - Vol.4. - Series: The problems of methodic of physics and mathematics and technological educational. - Part 2. Kirovohrad : RVV KDPU named after V. Vinnichenko, 2013. — P. 120-124. (in Ukrainian)

6. Ivanytska N. A. The model of competence of students / N. A. Ivanytska // Methods and technology of modern educational environment : Materials of conference, Kirovograd, 17-18 of May 2013 y. / Main editor: S.P. Veluchko. — Kirovograd : PP "Exclusive system”, 2013. — P. 100-101. (in Ukrainian)

7. Kalenik M. V. Methodic of organization of independent work of students with literature / M. V. Kalenik // Teaching Science: theory, history, technology innovation. - 2011. — №1 (11). — P. 188-194. (in Ukrainian)

8. Kozakov V. A. Self-training of students and information and methodological support: Tutorial. - K. : High school, 1990. — P. 15 (in Russian)

9. Moroz V. D. Self-training students : monograph / Moroz V. D. - H. : HMK, 2003. - 64 p. (in Ukrainian)

10. Pedagogika / P.I. Pidkasisty. - M. : Pedagogika, 1996. - 602 p. (in Russian)

11. Petrova A. V. Teaching condit ons of independent teaching and learning of students / A. V. Petrova // Native school. — 2006. — № 7. — P. 16-19. (in Ukrainian)

12. Regulations on distance learning [online]. - Available from : http://zakon1.rada.gov.ua/laws/show/z0703-13 (in Ukrainian)

13. Programs for school education. Research and experimental direction / O. O. Artemyeva, S. U. Bilous, O. V. Bikovska. - K. : TOV "Information Systems", 2010. — Vol. 1. - 150 p. (in Ukrainian)

14. Sigaeva L. E. Abilities and skills of independent work in the professional formation of an adult: Textbook / L. E. Sigaeva, M. G. Gordienko. - K. : "EKMO", 2007. — P. 114-127. (in Ukrainian)

15. Soldatenko M. M. Theory and practice of self-learning of students : monograph / M. M. Soldatenko. K. : NPU named after M. P. Dragomanova, 2006. — 198 p. (in Ukrainian)

16. Gruber T. R. Translation approach to portable ontology specifications / T. R. Gruber // Knowledge Acquisition. - 1993. - Vol. 5. - P. 199-220. (in English)

17. Maedche A., Staab S. Tutorial on Ontologies: Representation, Engineering, Learning and Application // ISWC'2002. (in English) 